\title{
Introduction: Judeophobia and Islamophobia in France Before and After Charlie Hebdo and Hyper Cacher
}

\author{
JONATHAN JUDAKEN \\ Rhodes College, Memphis, TN, USA \\ E-mail: judakenj@rhodes.edu
}

\begin{abstract}
This article opens with an assessment of the narratives that emerged in the immediate wake of the Charlie Hebdo / Hyper Cacher events in January 2015. It does so by examining the differing hashtags of the moment—\#jesuisCharlie, \#jesuisjuif, \#LassBat—and how each offered a distilled account of what the moment meant; these competing interpretations were echoed in the news coverage and the commentary that followed. The article proceeds to set out how this special issue reframes and reevaluates the recent history of relations between Jews and Muslims in France. Each author suggests that Judeophobia and Islamophobia are inextricably entangled in ways more complicated than simple formulas or hashtags can encapsulate. Taking on the suggestion that "Muslims are the new Jews" in France (or in Europe), the special issue instead urges an appreciation of the interlocked vulnerabilities and insecurities of both Jews and Muslims. Such an approach requires a recognition of the structural and institutional forces and ideologies that have shaped their interconnected destinies in the last generation.
\end{abstract}

Keywords Antisemitism · Islamophobia · Post-Holocaust Judeophobia · Jews · Muslims · Charlie Hebdo

\section{Hashtag Wars}

The Charlie Hebdo events in January 2015 were France's 9/11. The spectacular acts of terror perpetrated by Saïd and Chérif Kouachi, who forced their way into the offices of the French satirical newspaper Charlie Hebdo on January 7 , murdering twelve, were followed on January 8 with the slaying of a police officer. This assault was coordinated with an attack by Amedy Coulibaly on the Hyper Cacher supermarket on January 9, killing four. Together, these avowed militants, who swore allegiance to al-Qaeda and ISIS respectively, viciously slew seventeen people: cartoonists, journalists, office employees, police officers, and Jews working and shopping in a kosher market. This was far fewer than those killed in the Paris attacks on November 13, 2015 - perpetrated outside the Stade de France, in several restaurants, and inside the Bataclan theater - that indiscriminately murdered 129 people and injured as many as 350 . But as in the United States, it was the response on January 11 to the Charlie Hebdo events, with the massive marche républicaine bringing four million French people into the streets-the largest rallies 
ever in France-and the global solidarity scrolling across social media created by the rallying cry \#jesuisCharlie, that cemented the Charlie Hebdo and Hyper Cacher attacks as a caesura in French history.

The significance of the moment was captured in the hashtag wars that followed. The most famous slogan, Je suis Charlie, was the spontaneous creation of Joachim Roncin, an artistic director at the magazine Stylist, who put it online at 12:52 p.m. on January 7. It instantly went viral. As Gilles Kepel notes, it "restored with a single click the lost universality of the French language and even the nostalgic illusion of the resilience of its values." ${ }^{1}$ In a phrase that needed no translation, Je suis Charlie opposed militant jihadi terrorism, which barbarically acted to silence free speech, one of the basic liberal freedoms of Western democracy and modern European civilization. But in doing so, it also reinforced the binaries that underpinned the debate about the magazine Charlie Hebdo: free expression versus racial insult; secularism versus religion; integration versus segregation; democracy versus totalitarianism; and civilization versus barbarism. ${ }^{2}$ As these polarities indicate, lurking beneath Je suis Charlie was a clash of values, if not civilizationsa rhetoric made familiar by Samuel Huntington-that the response to the Charlie Hebdo events had brought to the fore. ${ }^{3}$

In Qui est Charlie? Sociologie d'une crise religieuse (Who is Charlie? Xenophobia and the New Middle Class), Emmanuel Todd sought to point out how the discourse about the Charlie Hebdo attacks had an exclusionary logic. In his controversial polemic, he wanted to show how Je suis Charlie reinforced a republican France that was not Muslim:

The Republic that was being re-established placed the right to blasphemy at the heart of its values, with their immediate point of application being the right to blaspheme against the emblematic person of a minority religion, supported by a group that was discriminated against. In the context of mass unemployment, in which young people of North African origin find it particularly difficult to find work, and Islam is constantly being demonized by ideologues in high places in French society, on television as

\footnotetext{
${ }^{1}$ Gilles Kepel with Antoine Jardin, Terror in France: The Rise of Jihad in the West (Princeton, NJ, 2017), 173.

${ }^{2}$ On some of these oppositions, see Mayanthi Fernando and Catherine Raissiguier, "The Impossible Subject of Charlie Hebdo," Contemporary French Civilization 41, no. 2 (2016): 12544, 126.

${ }^{3}$ Samuel Huntington, The Clash of Civilizations and the Remaking of World Order (New York, 1996).
} 
in the French Academy, we cannot overemphasize the repressed violence that was present in the 11 January demonstrations. ${ }^{4}$

On the basis of a sociodemographic analysis, Todd maintains that the reaction to the Charlie Hebdo events that crystalized in the hashtag \#jesuisCharlie was the assertion of "a neo-republican system" that is dominated by the middle classes, but whose lowest sector suffers from neoliberal globalization and the imposition of austerity by the European Union. ${ }^{5}$ Those in that sector are anxious about their status but unanchored from the metaphysical certainties of the past. The rise in Islamophobia provides a point of cohesion. But the stereotyped "Muslims" that they fear are a phantasm. This is because there is no homogenous group to which this label can be affixed. ${ }^{6}$ These neorepublicans are also disturbed by the rise of the extreme Right. So they "fight a war on two fronts: against both [the] populism [of the National Front] and against Islamism."7

Todd also argues that the militant laïcité advanced by Charlie Hebdo actually helps to engender the antisemitism of Muslim youth that was at work in the attacks. ${ }^{8}$ Since many who support neorepublicanism are what Todd

\footnotetext{
${ }^{4}$ Emmanuel Todd, Who is Charlie? Xenophobia and the New Middle Class, trans. Andrew Brown (Cambridge, 2015), 67-68.

${ }^{5}$ For a compelling critique of Todd's underlying methodology that led to his conclusions, see Nonna Mayer and Vicent Tiberj, "Le simplisme d'Emmanuel Todd démonté par la sociologie des 'Je suis Charlie,"' Le Monde, May 15, 2015.

${ }^{6}$ Four-fifths of Muslims in France come from three different countries-Algeria, Tunisia, and Morocco-with the remainder coming from sub-Saharan Africa, primarily West Africa. They come from different generations and have differing levels of religious adherence. Most in the younger generations of Muslim descent are natives and citizens of France.

${ }^{7}$ Todd, Who is Charlie?, 190.

${ }^{8}$ The policy of Jewish History is to spell antisemitism without a hyphen. This is the preponderant position among Jewish studies scholars who maintain that hyphenating the term gives credence to the notion that "Semitism," "Semite," or "Semitic" refers to a real group of people- "the Semites"- who were once characterized as a race. But scholars who reject the hyphen also claim that for antisemites, "Semites" just stands for Jews, who are the sole object of contempt or hatred for "antisemites." This argument is either tautological or ahistorical. Additionally, many of the same scholars who advocate for this orthography claim that Judeophobia is unique in its persistence, key tropes, and consequences, differing essentially from Islamophobia or other forms of racism. I urge a reconsideration of this position in "Introduction: Rethinking Anti-Semitism," American Historical Review 123, no. 4 (October 2018): 1122-38. Drawing upon a significant body of scholarship, especially the work of my coeditor on this special issue, Ethan Katz, I show that for much of European history, the representations and fates of Jews and Muslims were entangled in complicated ways. Moreover, today Judeophobia and Islamophobia are inextricably bound together. One cannot understand the one without the other. This is the clearest lesson of this special issue-hence I urged the hyphenation of "antisemitism." The orthographic question of whether to hyphenate antisemitism has always been both epistemological and political. To hyphenate "anti-Semitism" consciously today-
} 
terms "zombie Catholics," underpinning their worldview is a Christian antiJudaism now reworked to focus on Muslims. ${ }^{9}$ Muslims, who are a denigrated minority, then focus their frustration and discontent on Jews. A xenophobic feedback loop thus buttresses the social dynamics at work:

Xenophobia used to be confined to the poorer sections of society, but these days it is moving up to the top of the social structure. The middle and upper classes are seeking their scapegoat [via Islamophobia]. And then there was the disturbing way that the commentaries underplayed the anti-Semitic dimension of the event, even though it came after the killings in Brussels in May 2014 and Toulouse in March 2012. The real question for France is not the right to caricature, but the rise of anti-Semitism in the suburbs. Racism is spreading toward the top and the bottom of the social structure at the same time. ${ }^{10}$

Todd here references a spree of attacks by militant Islamic terrorists and how their Judeophobia is dialectically linked to Islamophobia. His critical interpretation of the January 11 demonstrations and the framing of the Charlie Hebdo events consequently raises some disturbing points about just who Charlie represents.

Todd also makes it clear that Je suis Charlie misses what other slogans captured. This was, after all, a double attack that clearly targeted Jews as such, captured by the hashtag \#jesuisjuif. Nonetheless, as Gayle Zachmann emphasizes, "the subjects of Jews and anti-Semitism were conspicuously absent from initial reports, and this even when the hostage situation and the site of the supermarket were shown with the word Cacher (kosher) on the screen behind announcers." 11 This silence points to the tenuous position of Jews

by drawing attention to the hyphen as signifying an entangled history-points to the historical intersections and interactions between Jews and Muslims, while nonetheless remarking upon the myth of "the Semite" that underpins the origins of the term. It also endeavors to rebuff the assertion made by those who refuse to hyphenate anti-Semitism because they insist on the unique targeting of Jews. The choice to hyphenate is particularly significant in a political frame where Jews and Muslims are often figured as perpetual enemies, despite the historical scholarship that shows otherwise. I hope that this special issue and the body of work referenced in the American Historical Review roundtable "Rethinking Anti-Semitism" will lead to a reconsideration of the question about hyphenating "anti-Semitism."

${ }^{9}$ Todd does not directly define what he means by "zombie Catholics," but from his usage it is clear he is referencing post-Catholics or those who come from a milieu that was once Catholic and whose culture is thus shaped by a Catholic past no longer active but still unconsciously alive.

${ }^{10}$ Todd, Who is Charlie?, 6-7.

${ }^{11}$ Gayle Zachmann, “The Happy Jew: Legacies, Crises, and Post-Charlie Hebdo Conscience," Contemporary French Civilization 41, no. 2 (2016): 279-86, 280. 
in France, whose particular insecurity as a group often goes unremarked in public discussions lest the republican social contract that buttresses Jewish emancipation be violated by any reference to what the French term communautarisme (communal identity), as distinct from individual citizenship. For the quid pro quo of civic equality in France is that no communal groups draw attention to what differentiates them from all other French citizens.

For Jews, however, the Hyper Cacher assault was only one of a series of antisemitic attacks, and the silence about it was equally serial. Six months prior, during the Israeli incursion into Gaza in the summer of 2014, demonstrators against the war carried signs that read: "Israel Murderer, Hollande Accomplice," while protestors marched shouting, "Death to Jews" and "Death to Israel." Others took selfies while gesturing using the quenelle, the Judeophobic comedian and activist Dieudonné's reworking of the Hitler salute, which supposedly decries "the system" that Dieudonné suggests Jews, Israel, and America control. That summer there were also a spate of firebombings of synagogues. As Todd mentions, a year earlier, Mehdi Nemmouche, a French national of Algerian origin who had spent a year with ISIS in Syria, gunned down four people at a Jewish museum in Brussels. But the key turning point in militant jihadi Judeophobia was in March 2012, when Mohammed Merah killed three young French soldiers of Maghrebi descent who he deemed "apostates" in the town of Montaubon before entering Ozar HaTorah, a Jewish day school in Toulouse, where he murdered three children and a teacher. Judeophobic attacks doubled in France in the year following the Charlie Hebdo events. Globally, 2015 gave rise to the highest number of assaults on Jews and Jewish institutions in seven years. This precipitous increase came at the end of a tenfold escalation over the years since antisemitic incidents have been closely tracked, intensifying especially in the wake of the Second Intifada in September 2000. France has averaged nearly six hundred antisemitic incidents yearly since then. While Jews top the list of those targeted by racism, Ethan Katz notes that "Muslims were next, with more than 2,700 anti-North African, anti-Arab, or anti-Muslim incidents recorded from 2000-2011."12

As Alec Hargreaves explains, since the 1990s, the Commission nationale consultative des droits de l'homme has published annual reports based on police data about incidents of antisemitism, racism, and xenophobia. Within this data set, "racism serves de facto to denote all forms of racially or ethnically motivated offences-be these on the basis of skin color, real or supposed religious affiliations, or national origins-except for anti-Semitism,"

\footnotetext{
${ }^{12}$ Ethan Katz, The Burdens of Brotherhood: Jews and Muslims from North Africa to France (Cambridge, MA, 2015), 315.
} 
which is tallied in its own category. ${ }^{13}$ While in the 1990s antisemitic incidents were far outnumbered by other racist acts, since 2000 Judeophobic incidents have sharply escalated, tending to spike in relation to every major event in the Israeli-Palestinian conflict or in the Middle East more broadly. Prior to 2000, post-Holocaust Judeophobia was primarily attributed to extreme-right groups, while subsequently, in cases where perpetrators have been caught, more than two-thirds have been carried out by male youths of North African origin. ${ }^{14}$ This is in a context where the largest population of Muslim heritage (five million or more) lives side by side with the largest Jewish minority in any West European country (around five hundred thousand to six hundred thousand).

But just as Todd questions the reductive narrative invoked by \#jesuisCharlie, \#jesuisjuif reduces the complexity of what is going on between Jews and Muslims in France today to a rise in antisemitism. This is belied by the third hashtag, \#LassBat, and the slogan Je suis Lassana Bathily. It invokes the bravery of the Hyper Cacher employee who shares the Malian, Muslim background of the murderer Coulibaly. Bathily secreted several of the shoppers in the store into a basement cold storage room to save their lives. The common background of Bathily and Coulibaly - the one a rescuer of Jews, the other an attacker targeting them-makes evident that one cannot account for their actions by relying on their national origins or their Muslim heritage or a unitary Islamic ideology. ${ }^{15}$ Vying for recognition also was the hashtag \#jesuisAhmed, naming and mourning the forty-two-year-old police officer of Arabo-Muslim descent, Ahmed Merabet, killed by the Kouachi brothers as they fled the Charlie Hebdo offices. As Mayanthi Fernando and Catherine Raissiguier have noted, even more unnoticed were the slogans that declared Je suis Clarissa and Je suis Elsa, referring to the female victims of the attacks. ${ }^{16}$ Indeed, if the complicated dynamics between Jews and Muslims and Judeophobia and Islamophobia invoked in \#LassBat require deeper scrutiny, such analysis is even more necessary for the gendered dimensions of the Charlie Hebdo events, which have received almost no attention until this special issue.

\section{Reframing Charlie Hebdo/Hyper Cacher}

Each hashtag or slogan-Je suis Charlie, Je suis Juif, or Je suis Lassana Bathily —offers only a truncated perspective on what Charlie Hebdo/Hyper

\footnotetext{
${ }^{13}$ Alec G. Hargreaves, "French Muslims and the Middle East," Contemporary French Civilization 40, no. 2 (2015): 235-54, 240.

${ }^{14}$ Hargreaves, "French Muslims, 241.

${ }^{15}$ Hargreaves, "French Muslims," 250.

${ }^{16}$ Fernando and Raissiguier, "Impossible Subject,” 132.
} 
Cacher means. The same might be said of much of the news coverage and instant analysis that appeared in the days, weeks, and months following the attacks. By contrast, bringing together historically informed scholarship from a range of disciplinary vantage points enables us to consider current events within longer-term trajectories and larger frameworks of interpretation. This special issue provides a set of multidisciplinary reflections on what these incidents indicate about the linked lives of Muslims and Jews in France-and sometimes beyond the Hexagon-before and after Charlie Hebdo / Hyper Cacher. The contributors lay out a more encompassing, interlaced set of interpretations that place that moment into a broader set of contexts, both empirical and theoretical.

$$
* * * * *
$$

In the opening contribution, "The Carnival's Edge: Charlie Hebdo and Theories of Comedy," Matt Sienkiewicz engages on the metalevel with ideas about what makes irony and satire signify in the ways that they do-in short, what makes them funny. A scholar of media studies, Sienkiewicz parses the debate about Charlie Hebdo and the charge that its representations of Muslims were racist, a position developed in these pages by Sandrine Sanos. Rather than seeking to settle the argument, Sienkiewicz explores how theorists understand the nature of the humor itself. For example, he invokes Philippe Val, cofounder of Charlie Hebdo, who insists that properly understood, the magazine manipulated what Val terms "second-degree humor" (humor au second degré). This form of comedy exaggerates what is not funny (homophobia, misogyny, and racism) to such an extent that it becomes amusing. But Val is challenged by former Charlie Hebdo staffer Olivier Cyran, who asserted that since 9/11 "the obsessive pounding on Muslims to which your weekly [Charlie Hebdo] has devoted itself for more than a decade has had very real effects. It has powerfully contributed to popularising, among 'left-wing' opinion, the idea that Islam is a major 'problem' in French society. That belittling Muslims is no longer the sole privilege of the extreme right, but a 'right to offend' which is sanctified by secularism, the Republic." 17

Leading contemporary theorist of irony Linda Hutcheon maintains that such fundamental disagreements are intrinsic to all forms of irony. Chiding, provoking, even offending is basic to the genre. Without it, the political efficacy of sarcasm would be deadened. Unintended interpretations are indispensable to laughter. Without them people would never snicker at their

\footnotetext{
${ }^{17}$ Olivier Cyran, “'Charlie Hebdo,' pas raciste? Si vous le dites ...," Article11, December 5, 2013, translated by Daphne Lawless as "“Charlie Hebdo,' Not Racist? If You Say So ...," https://daphnelawless.com/charliehebdo/Charlie_Hebdo_article\%2011.htm.
} 
own frailty, thus undercutting their own legitimacy. This is what makes comedy transgressive and subversive. But the double edge is that people often laugh at what they find inferior and degrading. The most famous model of the subversive potential of satire is Mikhail Bakhtin's notion of the carnivalesque, which considers how jesters could use parody, bodily humor, and the upending of normative behavior to unsettle and destabilize those with power and authority. If for Bakhtin this had liberatory potential, for other literary critics like Umberto Eco it only served to release pressure without any genuine social implications. Central to the dispute about the political efficacy of the carnivalesque is the issue of hegemony: that is, whether the humor aims at those with cultural power or makes fun of the disempowered. In the latter case it obviously does not displace, but rather reinforces, social hierarchy. Sienkiewicz highlights how Charlie Hebdo provides a fitting test case for this question, as it has long prided itself on speaking for the powerless against the establishment but seemed to do much the opposite with its pejorative images of Muslims in the early twenty-first century.

Sandrine Sanos, an intellectual and cultural historian, moves us from the metalevel of comedic theory to the politics of representation. In her contribution, "The Sex and Race of Satire: Charlie Hebdo and the Politics of Representation in Contemporary France," Sanos draws our attention to the grammar that underpins the political language of race (both anti-Jewish and anti-Muslim), which she shows is linked to gender and sexuality. She underscores how gender has always been central to imagining the body politic. In doing so, she highlights a crucial feature that has been overlooked in the discussion of Charlie Hebdo. For as Fernando and Raissiguier note, there has been "little commentary on the gendered and sexual dynamics of the attacks and reactions they provoked in France and elsewhere." 18

Sanos traces the history of Charlie Hebdo from its transgressive New Left origins in the 1970s, when its scatological humor was nonetheless often homophobic and misogynistic, to its editorial stance after $9 / 11$, which she treats as symptomatic of a widespread discourse about the perversions of Muslim sexuality central to the racialization of Islam in France today. This is analogous to the representations of Jews in the 1930s and 1940s underlined by historical sociologist Pierre Birnbaum, who showed how Socialist Prime Minister Léon Blum, the archetypal Jew of the era for antisemites, was depicted as a hermaphrodite or homosexual, a sexual degenerate and predator who threatened France and European civilization. ${ }^{19}$ In Sanos's earlier work on French fascism, she elaborated on this by examining how interwar writers

\footnotetext{
${ }^{18}$ Fernando and Raissiguier, "Impossible Subject," 132.

${ }^{19}$ Pierre Birnbaum, "Hermaphroditism and Sexual Perversion," chap. 7 of Anti-Semitism in France: A Political History from Léon Blum to the Present (Oxford, 1992).
} 
like Louis-Ferdinand Céline and Robert Brasillach depicted the abject Jew as both a sexual and a racial threat. ${ }^{20}$ In her intervention here, she explains how a French fascist like Lucien Rebatet shifted from anti-Jewish novels in the Vichy era to anti-Arab writings in the context of the French-Algerian war in the 1950s. Sanos then details how the same debauched images of Arabs have been recycled in the contemporary era, including in the pages of Charlie Hebdo. She thereby signals a grammar of deviant sexuality defined in opposition to the norms of the nation whose targets were Jews in the 1930s and 1940s but today places Muslims in the crosshairs. She shows that the gendered rhetoric that emerges from this grammar constitutes a racializing discourse that is common across the political spectrum.

Sanos's insistence on the importance of gender and sexuality in contemporary Islamophobia points toward the salience of these issues for postHolocaust Judeophobia as well. For instance, Birnbaum's more recent work has documented the emergence of homophobia, misogyny, and anti-Jewish racism among both the Catholic Right, especially National Front supporters, and some Islamic groups. This was made apparent by their united "Protest for All" (Manif pour tous) campaign against the law authorizing same-sex marriage (Mariage pour tous) that erupted in anti-Jewish hostility. In the midst of the January 26, 2014, demonstration of the Day of Wrath (Jour de colère) that brought these groups into the streets to decry gay marriage and the teaching of gender equality, there was an outbreak of orchestrated shouting, including "Jew! Jew! This France is not your France," "France for the French," and "Death to Zionists!" Slogans like these not heard in the streets of Paris since the Vichy era were now mixed with newer anti-Zionist chants. More of the same types of racist mantras were to follow in the protests mentioned earlier against the Israeli incursion into Gaza in the summer of $2014 .^{21}$ Muslim support for both of these protests emerged as a wedge issue, dividing some citizens of Muslim heritage from the strong attachment to the left they had shown in the 2012 presidential elections. This would be followed by another conservative initiative, the Journées de retrait de l'école (JRE, or school boycott days) launched by Farida Belghoul, a teacher, author, and activist of Algerian descent who resisted the teaching of "gender theory" and ABCD de l'égalité (ABCs of equality [between boys and girls]) in French schools, since Belghoul insisted that they promoted homosexuality. The initiative was successful primarily in the Parisian banlieues, where as many as 30 percent of students, mostly of Muslim descent, stayed home from school to support the boycott. ${ }^{22}$

\footnotetext{
${ }^{20}$ Sandrine Sanos, The Aesthetics of Hate: Far-Right Intellectuals, Antisemitism, and Gender in 1930s France (Stanford, CA, 2012).

${ }^{21}$ Pierre Birnbaum, Sur un nouveau moment antisémite (Paris, 2015).

${ }^{22}$ Kepel, Terror in France, 140.
} 
Sanos also addresses the ridiculing of comedian Dieudonné M'bala M'bala in clichéd anti-African depictions by Charlie Hebdo, even as she remarks on Dieudonné's own Judeophobia. Dieudonné has played a key role in stoking his own form of racist rhetoric that I would term "banlieue Judeophobia." Born in France in 1966 to a Cameroonian father and a white mother, early in his career he toured with a Sephardi Jew, Élie Seimoun, in an act that often involved the two parrying ethnic insults back and forth, where homophobia was a standard part of the show. By 2003, however, Dieudonné appeared on a TV show dressed as a stereotypical rabbi who nonetheless offered up a Nazi salute during his routine and shouted "Israeheil." Dieudonné was thus doing to Jews in his live comedy what Charlie Hebdo was doing to Muslims with its cartoons. Since then he has repeatedly flouted French laws against hate speech by attacking Jewish personalities; courting Holocaust denial, even to the point of inviting Robert Faurisson, the star of French deniers, on stage with him in 2006; and inventing the quenelle gesture, which, as journalist Marc Weizman cogently explains, is an " 'anti-establishment' move ... that looks half like Nazi salute, half like a 'fuck you' gesture."23

Dieudonné's show mocking "the system" and "elites" and the "Empire" and "the Bank" sells out nightly to a diverse audience that adores "Dieudo" as their rebel with a cause, one who takes aim at Jews, Zionists, America, and Israel. This is comedy from a member of a vulnerable minority directed at another. By 2013, the Socialist government that sought to crack down on his performances was referring to "the Dieudonné phenomenon" that delivered not only through live shows but also through videos on YouTube and Facebook with a huge viral audience. When it looked as if Dieudonné would avert the ban on his performances demanded by then interior minister Manuel Valls, he tweeted on January 9, 2014, "Take that in the ass, Manuel!," thus deploying the same homophobic imagery often used by Charlie Hebdo.

Dieudonné has become strongly aligned with the Far Right journalist, essayist, and activist Alain Soral. They began working together to support the "anti-Zionist" slate for the European Parliament elections in 2009. If "Dieudo" is the figurehead, then Soral is the ideologist, explains Gilles Kepel. ${ }^{24}$ Soral's main medium is Égalité et reconciliation, a website that serves

\footnotetext{
${ }^{23}$ On Dieudonné, including this quote, see Marc Weitzmann, "Did a French Comedian Inspire the Killings at the Jewish Museum in Brussels? Links between Dieudonné, the Belgian Anti-Semite Laurent Louis, and Iran Show How Anti-Semitism Is Spreading in Europe," Tablet, May 27, 2014, http://www.tabletmag.com/jewish-arts-and-culture/theater-and-dance /174215/dieudonne. See also Alexander Stille, "The Case of Dieudonné: A French Comedian's Hate," New Yorker, January 10, 2014, http://www.newyorker.com/news/daily-comment /the-case-of-dieudonn-a-french-comedians-hate; Bruno Chaouat, "Postscript: Theorizing Antisemitic Laughter," in Is Theory Good for the Jews? French Thought and the Challenge of the New Antisemitism (Liverpool, 2016), 223-38.

${ }^{24}$ On Soral and his connection with Dieudonné, see Kepel, Terror in France, 49-52.
} 
both as an Internet forum and as a network for organizing meetings with titles like "La France, l'islam et les banlieues face à l'empire mondialiste" (France, Islam, and the banlieues against the globalist empire). Soral's agenda is to mobilize Muslims as part of a nationalist battle whose enemy is "Zionism," which has come to signify all evil worthy of opposition.

So while Sienkiewicz can help us to explain how Charlie Hebdo can make some laugh while others cry racism and Sanos can explicate the gendered dynamics at work in Charlie Hebdo's caricatures of Muslims that update an anti-Jewish legacy, Dieudonné and Soral complicate the question of who are victims and who are perpetrators, of who is powerful and where the sources of power lie. What none can deny is that the fate of Jews and Muslims and Judeophobia and Islamophobia are bound together.

The parallels between Jews and Muslims as symbols within the turbulence of global capitalism are at the heart of Dorian Bell's article "Europe's 'New Jews': France, Islamophobia, and Antisemitism in the Era of Mass Migration." A scholar of literature and critical race theory, Bell contends that if the spirit of modern capitalism was exemplified for many by the stereotype of the Rothschild banking house controlling the world, postmodern globalization has produced a new Jew, a new scapegoat, a new object to deflect the anxiety and alienation its disruptions produce. His launch pad is the burkini controversy: the call to ban the bathing suit that covers the whole body, except the face, hands, and feet, so as to preserve Muslim women's modesty. This sartorial controversy followed not only the Charlie Hebdo and the November attacks in 2015, but most immediately the devastating July 2016 terror attack in Nice, where an ISIS-affiliated murderer drove a cargo truck along the beachside Promenade des Anglais, killing eighty-six. Bell focuses our attention on the structural forces behind such events: the dislocations brought about by globalization, penetratingly analyzed by Benjamin Barber in $M c$ World vs. Jihad, which showed that mondialisation produces its twin in tribalism. ${ }^{25}$

Bell's analytic pedigree has its origins in Karl Marx's and Friedrich Engels's views on antisemitism, nuanced and refined by Frankfurt School theorists like Max Horkheimer and Theodor Adorno and elaborated in new forms most recently by Étienne Balibar, Alain Badiou, and Slavoj Žižek. Marx's On the Jewish Question (1843) claimed that global capitalism produces alienation and anxiety because it unmoors settled social relations. In the process, Marx infamously personified capitalism, identifying it with Jews and Judaism whose spirit was "practical need and egoism" embodied in the pursuit of mammon, which he claimed had now infected all culture. His key insight,

\footnotetext{
${ }^{25}$ Benjamin R. Barber, Jihad vs. McWorld: Terrorism's Challenge to Democracy (New York, 1995).
} 
however, was that the argument then raging about civic equality for Jews was beside the point. He was enjoining his readers to focus their attention instead on the structural effects of capitalism. ${ }^{26}$ Engels would later maintain more clearly that antisemitism was primarily a result of angst among the petit bourgeois about their status, which was threatened by the rise of capital development. ${ }^{27}$ A neo-Marxist line of critical theory would develop the insight. The Frankfurt School added a psychoanalytic spin to this economic explanation of antisemitism, clarifying in more variegated terms than Marx and Engels how the antisemitic image of "the Jew" was a paranoid screen against which antisemites projected and personified their nightmares of the dark side of industrialization and modernity. ${ }^{28}$ Bell rejuvenates this approach to account for what he terms the "new Jews" of twenty-first-century global capitalism: the abstract and hypostatized "Muslims."

Bell's key references in developing his argument are Žižek and Badiou, who each have theorized the implications of the growing gap between rich and poor, highlighting the shrinking middle class and its concomitant anomie. Žižek in particular has long insisted that "the ideological figure of the 'Jew' is invested with our unconscious desire" and that antisemitism consequently serves as an ideological "quilting point," a means not only to stitch up the inconsistencies within ideological systems but also to enable us to see how these ideological systems operate. ${ }^{29}$ Drawing upon this set of theoretical starting points, Bell maintains that one function of antisemitism historically was to personify the unjust benefactors of capitalism by insisting that Jews embodied them. He provocatively speculates that Islamophobia today personifies the threat of outsiders who might encroach on the gains of the middle class who want to shore up their social position. "Muslims" represent not the beneficiaries of capitalism as Jews once did, however, but rather its threat from below and from afar. For this reason, Bell foregrounds the beaches as sites not only where terrorists have used trucks as murder weapons but also where the state has fixated on what Muslim bathers wear when they enjoy the leisure time that capital promises. He thus highlights the economic dimensions of Islamophobia, as opposed to the concerns about religion or culture or politics that predominate in most discussions. In doing so, he puts

\footnotetext{
${ }^{26}$ Karl Marx, "On the Jewish Question," in The Marx-Engels Reader, ed. Robert C. Tucker, 2nd ed. (New York, 1978), 26-52, 50.

${ }^{27}$ Friedrich Engels, "Über den Antisemitismus," Arbeiterzeitung, May 8, 1890. Cited in Enzo Traverso, The Marxists and the Jewish Question: The History of a Debate, 1843-1943, trans. Bernard Gibbons (Atlantic Highlands, NJ, 1990), 26.

${ }^{28}$ For the Frankfurt School's approach to antisemitism, see Jack Jacobs, The Frankfurt School, Jewish Lives, and Antisemitism (Cambridge, 2015); Lars Rensmann, The Politics of Unreason: The Frankfurt School and the Origins of Modern Antisemitism (Albany, NY, 2017).

${ }^{29}$ Slavoj Žižek, The Sublime Object of Ideology (London, 1989), 48.
} 
a spotlight on an underacknowledged dimension of the fixation on Muslims within the West. But he also maintains that Islamophobia and Judeophobia are linked. Since historically "Jews" personified the (illegitimate) insiders of capitalism, today Judeophobia among Muslims repurposes this myth. The result is a dialectic where Islamophobia necessarily produces Judeophobia.

But since these phobias are dialectically connected, framing the discussion in terms of an argument about Muslims as the "new Jews" risks misdirecting readers and overly schematizing some of Bell's core insights. In Anti-Semitism and Islamophobia, an earlier, very influential iteration of the "new Jews" argument, Matti Bunzl maintained that xenophobic exclusions of Jews corresponded to the era of European nation-states; today these nations are being integrated into the European Union and Muslims are the excluded Other against which European identity is consolidated. ${ }^{30}$ But as several critics of Bunzl pointed out in response to his "new Jews" argument, nations and nationalism are hardly dead as state formations and nationalist politics continue to shape the dynamic between Jews and Muslims. ${ }^{31}$ One aspect of this dynamic is the deadly mix of banlieue and militant jihadi Judeophobia in France today. As we have seen, the hard-core Catholic and ethnonationalist discourse of the extreme Right and the hard-core anti-Zionism of the extreme Left also target Jews or Zionists as embodiments of what they find pernicious. So Judeophobia has not been superceded, as may be implied in claims about the "new Jews." Moreover, Žižek, and especially Badiou, have served as intellectual enablers of this Far Left discourse in France, blaming anti-Jewish violence on Israel and Zionism. At the same time, they claim that cries about a crisis of antisemitism in France are part and parcel of the campaign to stigmatize Muslims, thus abetting the denial of the new Judeophobia. ${ }^{32}$ In sum, where too many of the adherents to the "new Jews" argument fail is in recognizing Jewish vulnerability and Jews' sense of being imperiled. This recognition is at the heart of Kimberly Arkin's analysis.

In effect, if both Sanos's and Bell's contributions offer fresh and incisive takes on Muslims as France's "new Jews," the final two articles in the special issue reject such a framing. Arkin, an anthropologist, is keenly attuned to those who responded to the Charlie Hebdo events under the banner of Je

\footnotetext{
${ }^{30}$ Matti Bunzl, ed., Anti-Semitism and Islamophobia: Hatreds Old and New in Europe (Chicago, 2007), 1-46.

${ }^{31}$ Bunzl, Anti-Semitism and Islamophobia, 47-104.

${ }^{32}$ For a critique of Žižek and Badiou, see Chaouat, Is Theory Good for the Jews?, 66, 175-77. On Badiou, see Maurice Samuels, The Right to Difference: French Universalism and the Jews (Chicago, 2016), 162-65, 172-85; Sarah Hammerschlag, The Figural Jew: Politics and Identity in Postwar French Thought (Chicago, 2010), 261-67; Éric Marty, Une querelle avec Alain Badiou, philosophe (Paris, 2007), 11-127; Philippe Zard, "Un étrange apôtre: Réflexions sur la question Badiou," Plurielles 13 (2007): 89-96.
} 
suis juif. In her article, "Talking about Antisemitism in France Before and After Charlie Hebdo and Hyper Cacher," she documents how the most visible and threatening Judeophobic incidents have changed from the first to the second decade of the new millennium: from acts of vandalism, theft, and interpersonal violence to spectacular terrorism and mass murder that began with Merah's attack in Toulouse. She considers also how many French Jews have adopted a narrative that pays little heed to these shifts. Instead, they have come to understand all of these acts of Judeophobic violence by Muslims as endemic to an eternal Islamic anti-Judaism.

In the early 2000s, French Jews felt abandoned by the lack of response from governmental leaders in recognizing and opposing the Judeophobia that flared in the early years of the Second Intifada. Persisting attacks for the past two decades have increased the sense of isolation and misunderstanding felt by many Jews, some of whom feel increasingly alienated from a sense of Frenchness as a result. The Merah murders in Toulouse cemented the representation of Islamic Judeophobia as the heartbeat of Islamic jihad. This was accelerated in the Charlie Hebdo and Hyper Cacher events. Charlie Hebdo clearly identified Islamism with antidemocratic, anti-French, anti-Western attitudes. Jews' contentions that their targeting by Islamic terrorists represented the tip of the spear for the assault on police and other state authorities, freedom of the press, laïcité, and Western modernity acquired a more general hearing. More and more Jews have conjoined such an outlook to an eternalist account of Islamic Judeophobia and maintain that this indicates why Jews in France are like Israel within the nation-state system: they are the proverbial canaries in the coal mine within this clash of civilizations. This story consoles them, Arkin explains, since it reinforces a sense of ontological or even racial difference between Jews and Muslims within postcolonial France. This assertion of an essential difference belies the sociological realities of their positions within the French post-imperial nation-state, and it denies the colonial past that shapes both Jewish and Muslim destinies in France and in Israel. ${ }^{33}$

Arkin concludes her interrogation of the narratives that circulate around antisemitism in France today with a set of questions about how scholars might approach what I would term post-Holocaust Judeophobia, as opposed to the more common concept of a "new antisemitism." There are currently two camps, she explains. The first, the "new antisemitism" proponents-the intellectual wellspring for more popular accounts—dwell on ideology. They sound the alarm bells about how combating the new Judeophobia entails recognizing that it is congruent with Islamism, or even with Islam itself, and that

\footnotetext{
${ }^{33}$ For a much deeper analysis, see Kimberly Arkin, Rhinestones, Religion, and the Republic: Fashioning Jewishness in France (Stanford, CA, 2014), chap. 1. See also Maud Mandel, Muslims and Jews in France: History of a Conflict (Princeton, NJ, 2014), chap. 1; Ethan Katz, Burdens of Brotherhood.
} 
Israel is on the front line of this assault. The second camp focuses on sociology, historicizing the relative privilege of Jews in socioeconomic terms and detailing how this results from a different colonial and postcolonial set of discourses and practices about Jews and Muslims. Arkin suggests that the split between ideology and sociology needs to make space for a third approach that she terms "phenomenological"-one that is sensitive to the deep feelings of insecurity and vulnerability that many Jews feel despite their relative privilege.

For those seeking to understand the most recent events that have spurred such feelings among French Jews, Ethan Katz offers a valuable starting point in his contribution, "Where Do the Hijab and the Kippah Belong? On Being Publicly Jewish or Muslim in Post-Hebdo France." In his book The Burdens of Brotherhood: Jews and Muslims from North Africa to France, Katz, a social and cultural historian, established in detail how the French Jewish postcolonial condition is structured by longer-term colonial and postcolonial policies and narratives. ${ }^{34}$ Without invoking the hashtag \#LassBat in his contribution here, Katz updates the entwined fate of Jews and Muslims that he historicizes at much greater length in his monograph. He invokes a series of flash points since Charlie Hebdo / Hyper Cacher that exemplify how the fates of Jews and Muslims in France are bound together. He discusses the controversy about the "substitution menu"-a list of options that offer a substitute for pork when it is on the menu at school cafeterias-that erupted in March 2015. The "kippah affair" followed in January 2016. It unfolded in the wake of an ISIS-inspired attacker who used a machete to knife a Jew wearing a kippah and carrying a tractate of the Talmud, leading to a debate about whether Jews should hide their religious head coverings to avoid such attacks. In August 2016, the burkini affair, which is the focus of Bell's article, was in the headlines. In case after case, what Katz emphasizes is that discussions of Muslims and Jews in France are a triangular affair in which the French imperial Republic navigates its values and politics via considerations of the proper place of religious minorities in French society.

Katz's intervention is framed by an examination of the French preoccupation with laïcité, which is ultimately the framework for discussions of cafeteria menus and the sartorial choices of Jews and Muslims. In both cases, the ritual nature of their religions is construed as a problem for the French public sphere as a secular space. Olivier Roy in Secularism Confronts Islam has helpfully parsed how this situation arose. ${ }^{35}$ Roy insists on the necessary untranslatability of laïcité, the better to distinguish it from secularism or secularization, "whereby society gradually emancipates itself from religion

\footnotetext{
${ }^{34}$ Katz, Burdens of Brotherhood.

${ }^{35}$ Olivier Roy, Secularism Confronts Islam, trans. George Holoch (New York, 2007).
} 
without necessarily denying it." 36 He insists that laïcité, in contrast, should be understood as a political category deployed to manage minority differences. As is the case with the republican model of universalism of which it is a part, laïcité is a legal principle that has wavered between the right to equality of religion that was its dominant strand in the nineteenth century (whereby Jews, for example, insisted upon equal rights with Protestants and Catholics) and the right to separation from religion in the public square, ensconced in the 1905 law separating church and state. ${ }^{37}$ More recently, explains Roy, laïcité has become an ideology that "implies a conception of values, of society, of the nation, and of the Republic, based on the philosophy of the Enlightenment, the idea of progress, and finally advocacy of an ethics not rooted in religion but proclaimed as rationalist." 38 Parsing these differing discursive and juridical layers is key to understanding the root of positions advanced by individuals, political parties, and legal practices.

Katz underscores that the Jewish position in these discussions is characterized by ambivalence. The position of Muslims, in contrast, is more generally discussed today in rhetoric akin to the regenerationist discourse about Jews in the era of their emancipation (i.e., that the secular Republic guarantees equal rights to Muslim citizens only insofar as they renounce their communal identity, as they are constantly called upon to do, which will lead to their integration). Jews have navigated this discourse and set of practices in France since the French Revolution and are consequently discussed today more often as a model than as a problem, in contrast to Muslims. Colonial history is also key to understanding this dichotomy, since the ethnoracial separation of Jews and Muslims and the claim that Jews were more suited to adaptation and integration to French mores and laws was integral to their colonial experience. Katz thus brings home what emerges as the leitmotif of this special issue: the entanglement of Jews and Muslims and how this impacts Judeophobia and Islamophobia today.

By the conclusion of this issue, readers will appreciate how the different hashtags that emerged on social media each distilled distinct narratives not only about Charlie Hebdo / Hyper Cacher and its significance but also about the place of Jews and Muslims in France today. They will understand why the aftermath of Charlie Hebdo has occasioned fundamental disagreements about the event's significance both on the metalevel and on the level of the political ramifications of the magazine's representations. They will appreciate the structural forces that make Muslims and Jews vulnerable, but also the

\footnotetext{
${ }^{36}$ Roy, Secularism, 15.

${ }^{37}$ On the relationship between laïcité and French universalism and how these have changed over time, see Samuels, Right to Difference, 190.

${ }^{38}$ Roy, Secularism, 16.
} 
social conditions and ideological narratives that turn them upon one another as enemies. They will understand how antisemitism has changed in an era stoked by banlieue Judeophobia and militant jihadist assaults, but also how Islamophobia fosters and feeds these social facts. In short, the reader will appreciate how multiple frames of reference generated by a diversity of disciplinary insights are required to interpret Judeophobia and Islamophobia in the wake of Charlie Hebdo / Hyper Cacher. 